\title{
Transparency report disclosure practices of large- and medium-sized audit firms in South Africa
}

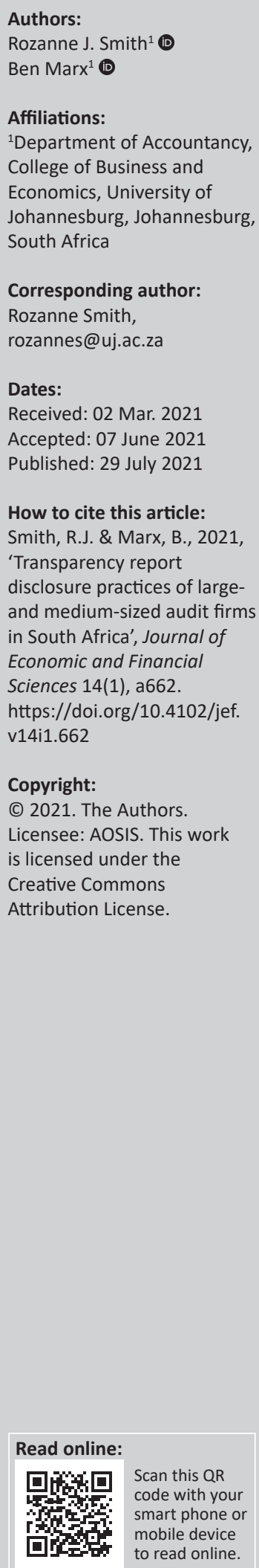

Research purpose: The purpose of this study is to examine the corporate governance practices disclosed by large- and medium-sized audit firms in South Africa, with a particular focus on transparency reports. Audit firms serve the public interest.

Motivation for the study: This study was motivated by recent corporate failures in South Africa, such KPMG, VBS Bank, and Steinhoff, to mention a few.

Research approach/design and method: The research approach followed for this study consists of a mixed method approach. Qualitative secondary data were obtained from publicly accessible information published on the websites of the audit firms. The data, which consisted of the firms' transparency reports, were analysed through content analysis. The results were then converted into quantitative data.

Main findings: The main findings reveal that audit firms in South Africa do not disclose sufficient corporate governance information in their transparency reports. There are inconsistencies between audit firms.

Practical/managerial implications: In South Africa, audit firms do not have a corporate governance code for audit firms, and thus audit firms are not disclosing the relevant corporate governance information to their stakeholders.

Contribution/value-add: This article contributes to the limited literature available on audit firm governance. Based on the findings, the study proposes best practice recommendations and regulatory and statutory recommendations regarding audit firm governance.

Keywords: corporate governance; audit firms; independence; stakeholders; public interest; EXCO; oversight board; transparency report disclosure.

\section{Introduction}

Fraudulent financial reporting and corporate collapses are often associated with audit failures. In these instances, it is believed that the auditors failed in their duty as 'watchdog' of the users of financial statements by letting fraud pass by undetected. Such failures have been ascribed to the poor governance practices and values within audit firms (Crotty 2019:n.p.; Sikka 2003:188). These failures have highlighted the need to reform the practices and values adopted by audit firms to restore public trust in the work of auditors (Amirul, Salleh \& Abu Bakar 2015:633; Crotty 2019:n.p.; Sikka 2003:189).

In 2010, the Financial Reporting Council (FRC) issued the United Kingdom (UK) Audit Firm Governance Code - the only such code in the world. The code was drafted to serve the interests of shareholders of listed companies to whom auditors address their reports. The objective of this code is to ensure that audit firms uphold best practice governance to enhance the transparency of audit firm's reporting and to improve the way in which audit firms are managed. Ultimately, the code also aims to strengthen the regulatory regime by promoting effective governance without disproportionate regulation (FRC 2010). Unfortunately, shortcomings are still evident in the corporate structures of some audit firms, which fail to apply codes of corporate governance (Abedian 2019:n.p.).

To enhance transparency and support audit firm quality and governance, audit firms are expected to release any information that might affect market confidence. This information should be released in the form of a transparency report (TR) (or similar type of report) (Kumar \& Zattoni 2014:3; Mallin 2002; Organisation for Economic Co-operation and Development [OECD] 2015). In 2018, in South Africa, the Independent Regulatory Board for Auditors (IRBA) issued a call to audit firms to release transparency reports to disclose relevant internal information to the public. To date, the publication 
of such transparency reports has been voluntary, although it is envisaged that this requirement will become compulsory in the foreseeable future (IRBA 2018).

The International Auditing and Assurance Standards Board (IAASB) (2014) indicated that audit firms transparency reports will assist third parties, such as the public and users of audited financial statements, to understand the characteristics of the individual audit firms and the drivers of audit quality in those firms. The IAASB further states that by displaying their approach to audits to the public in transparency reports, audit firms can compete on aspects of audit quality (Deumes et al. 2012:1). The IRBA (2018) added that transparency reports provide stakeholders with insights into an audit firm's corporate governance processes and structures.

This study determines whether large- and medium-sized South African audit firms release transparency reports and identify which corporate governance information, as indicated in the UK Audit Firm Governance Code, is disclosed by these firms. This study is pertinent in the context of South Africa following the recent spate of high-profile corporate failures such as VBS Mutual Bank, Nkonki, KPMG and Steinhoff, to name a few (Bowker, Bonorchis \& Wild 2017:n.p.; Cotterill 2017:n.p.; Crotty 2019:n.p.; Harber 2018:18; Hosken 2017:n.p.; Pilling 2017:n.p.; Shoaib 2017:n.p.).

The structure of this article is as follows: firstly, a literature review is conducted, after which the empirical evidence is presented in tables. A content analysis is then performed to determine the corporate governance disclosures in the transparency reports of the top nine audit firms in South Africa. Thereafter, the findings will be discussed and recommendations will be provided in the conclusion.

A delimitation of the study is that it only focuses on the top nine South African audit firms. Consequently, future research could be extended to include smaller audit firms and firms in other countries. Moreover, the study only focuses on the disclosure principles contained in the UK Audit Firm Governance Code; therefore, not all the principles contained in the code are considered.

\section{Literature review}

Corporate governance disclosures of listed companies have been researched and explored in several fields (Bauwhede \& Willekens 2008:101; Collett \& Hrasky 2005:188; Markarian, Parbonetti \& Previts 2007:294); however, very little empirical evidence exists on the corporate governance practices and disclosures of audit firms (La Rosa, Caserio \& Bernini 2018:15).

It is important that audit firms understand their responsibility to implement corporate governance principles and establish independent governance structures within their firms. They also need to understand the value that this could add - not only to the firm, but to all stakeholders. Currently, in South Africa, there is no legislation or code that regulates the corporate governance of audit firms. Consequently, there is no law that requires audit firms to report on their corporate governance structure and its application. Although the IRBA (2018) encouraged audit firms to issue transparency reports, this is not compulsory. Moreover, the firms that do issue such transparency reports only provide limited information, tending to focus on audit quality and largely ignoring governance.

As stated by the IRBA (2017), a lack of independence, integrity and professional scepticism in audit firms is seen as the primary cause of corporate scandals. It is also evident from the transparency reports of large audit firms in South Africa that the governance structures of most of these firms do not adhere to the requirements of the South African corporate governance code, namely the King IV Report on Corporate Governance, particularly in terms of board composition and independence. According to Nkuhlu (2020:6), corporate failures are a consequence of audit firms becoming commercial enterprises driven by revenue and profits for the partners. He adds that a lack of independence and 'cosy' relationships with clients result in corporate failures. The lack of a corporate governance code for South African audit firms could contribute to the poor application and disclosure prevalent in audit firms.

\section{Lack of corporate governance in audit firms}

The audit profession takes on the responsibility of detecting and reporting fraud and verifying their clients' ability to apply and disclose governance matters (Teck-Heang \& Ali 2008:4). Despite the fact that audit firms see themselves as the 'intellectual hub' of corporate governance best practice, few have a trustworthy and compliant board of directors (Abedian 2019:n.p.). Audit firms should have board of directors with a majority of non-executive directors, who are suitably balanced in terms of their mix of abilities, to comply with corporate governance requirements (Abedian 2019:n.p.). At present, the corporate structures of audit firms are flawed. Some audit firms argue that they need not comply with the codes of corporate governance because their business model is based on a 'partnership' (Abedian 2019:n.p.). According to Nkuhlu (2020:6), all audit firms need to appoint independent non-executive directors (INEDs) and place risk and ethics under their oversight. Equally, it is important for audit firms to disclose their corporate governance to all stakeholders given that they serve the public interest. Audit firms need to understand the importance of being transparent and the value of releasing transparency reports.

\section{Importance of disclosure and transparency reporting}

To date, there is limited research on transparency reporting in audit firms. A study conducted by $\mathrm{Fu}$, Carson and Simnett (2015:33) on the governance structures of audit firms in Australia found that information on board composition was not specified in the transparency reports and that relatively few audit firms disclosed any further details about their boards. According to a study by La Rosa et al. (2018:30), investors believe that transparency reports 
provide meaningful information about audit firm's quality and independence. A 2019 study by the same authors suggests that transparency on corporate governance issues by all organisations, including audit firms, contributes to the sound development of financial markets. The IRBA (2018) supported these findings, stating that transparency reports provide all stakeholders with insight into an audit firm's corporate governance processes and structures. Patel (2013) argued that transparency creates a level of non-secrecy and openness about information in companies. It is an effective way of protecting the interests of stakeholders insofar as it promotes the disclosure of non-financial information. This holds governing bodies accountable for the decisions that directly or indirectly affect stakeholders (Frederick 2000:n.p.; Fung 2014:73). The Brydon Report (2019), released by the UK government about the quality and effectiveness of audit, also provides recommendations for greater disclosure to promote trust in the corporate auditing profession.

In its call on South African audit firms to voluntarily release transparency reports, the IRBA should collaborate with both the audit firms and TR users to decide on the minimum contractual criteria that should be reported on annually. These reports should allow consumers to understand a company's commitment to audit quality, leadership, culture and ethics, risk management procedures, employee and service provider relationships and independence (IRBA 2019). To date there is no corporate governance code in South Africa specifically for audit firms. The lack of 'tailormade' audit firm guidelines on corporate governance does little to strengthen the weak application and disclosure of corporate governance principles by audit firms.

\section{Legislation or regulations that govern audit firms}

In South Africa, the fourth iteration of the King Report on Corporate Governance (King IV) is available to organisations to guide their corporate governance application and disclosure. Published in 2016, King IV is a framework that can be adopted across listed and unlisted companies, profit and non-profit organisations and public and private entities (Institute of Directors in Southern Africa [IoDSA] 2016). King IV also includes supplements that provide high-level guidance and direction on how the report should be interpreted by a variety of sectors and organisation types. Unfortunately, there is no supplement for audit firms (IoDSA 2016). A key objective of King IV is for its recommendations to be fit for application by different types of organisations and sectors. This implies that even audit firms should be able to apply King IV (IoDSA 2016). Yet, given the recent spate of corporate failures in South Africa, there is clearly a lack of application of King IV by audit firms in the country. According to Professor Nkuhlu (2020:6), the chairman of KPMG South Africa, KMPG is one of the very few, if not the only, audit firm to apply King IV.

Other legislation in South Africa that governs the audit profession is the Audit Profession Act No. 26 of 2005 (APA). Unfortunately, the APA does not have a specific chapter providing guidance on the governance of audit firms.
Chapter II, Part 4 only contains details on the governance of the regulatory board, namely the IRBA.

International legislation for the audit profession includes standards issued by the IAASB. In 2009, International Standard on Quality Control (ISQC) 1 was issued, entitled Quality Control for Firms that Perform Audits and Reviews of Financial Statements and Other Assurance and Related Services Engagements. This standard is applicable to all audit firms; however, it makes no specific reference to audit firm corporate governance, referring instead to individual auditors (IRBA 2018). In 2015, the IAASB issued the 'Invitation to Comment (ITC): Enhancing Audit Quality in the Public Interest: A Focus on Professional Scepticism, Quality Control and Group Audits'. This publication introduced the topic of transparency reporting. According to the ITC, firms are required to release transparency reports that provide information on certain elements of the firm and its operations (IRBA 2018).

British businessman, Sir Donald Hood Brydon, is the author of the Brydon Report, published by the UK government in 2019. The report discusses the quality and effectiveness of audit, stressing that there are certain principles that should guide the behaviour of auditors, beyond simply following standards and the law (Brydon 2019:6). However, the Brydon Report makes no specific reference to audit firm corporate governance; instead, the emphasis is once again placed on the individual auditor and not the firm.

According to the South African Auditing Profession Trust Initiative (SAAPTI) (2020:10), there is a need to clearly lay down the principles and best practices that audit firms should apply to achieve good governance (setting the 'tone at the top'). Governance structures for audit firms should be clearly defined. According to SAAPTI (2020:49), there is uncertainty as to whether audit firms have ethical leadership and are structured in a way that encourages them to act as good corporate citizens serving the public interest. To this end,SAAPTI(2020:87) has developed some recommendations, although these are still in draft format.

From the literature reviewed, it is noticed that the United Kingdom is the only country in the world with a corporate governance code specifically designed for audit firms. Given that South Africa's first King report, King I, was based on the UK's Cadbury Report (Mangena \& Chamisa 2008), it is submitted that the UK Audit Firm Governance Code could be used as the foundation to develop guidelines for South African audit firms.

\section{Research methodology}

In this study, content analysis was used to analyse the qualitative data. This method examines written, verbal or visual communication messages (Cole 1988; DowneWamboldt 1992:314). Researchers consider content analysis as a flexible method for scrutinising text data (Cavanagh 1997).

Informed by the UK Audit Firm Governance Code, a checklist (Appendix Table 1-A1) was created to analyse the corporate 
governance disclosure of South African audit firms. A comparison between King IV and the UK Code found that many of the King IV principles were already addressed in the UK Code, making it relatively easy for South African audit firms to apply these principles. As the King Code was initially developed based on the Cadbury Report (Mangena \& Chamisa 2008), it is submitted that the UK Audit Firm Governance Code could also be used as the foundation to develop guidelines for South African audit firms. It should be noticed that only the UK Audit Firm Governance Code principles that deal with disclosure were used for the purposes of this study.

The study used secondary data, namely the 2018 and 2019 transparency reports obtained from publicly accessible information published on the websites of the audit firms. Secondary data were also obtained by means of a literature review. Each of the transparency reports was analysed against the checklist. This list contained 'yes' or 'no' questions, asking whether the item stated in the checklist was present in the reports. This information was used to quantify how many firms disclosed the relevant information. The answers were then extracted from Excel and entered into the International Business Machines Corporation (IBM) Statistical Analysis Software Package (IBM SPSS) for analysis.

The study adopted a constructivist approach. This method seeks to clarify the world of human experience (Cohen \& Manion 1994:38) based on the premise that reality is socially constructed (Mertens 2005:2). The constructivist researcher focuses on the participants' impressions of a situation (Creswell 2003:9) and acknowledges the importance of their own history and experience. In general, constructivists do not begin with a hypothesis (as with post-positivists), but rather, they inductively produce a hypothesis or pattern of meanings (Creswell 2003:9). They do so in a manner that confirms or extends qualitative data and deepens the context (Mackenzie \& Knipe 2006:4).

The study population consisted of the large- and mediumsized audit firms in South Africa, as determined by the IRBA (2020:n.p.). These firms have 20 or more audit partners. The transparency reports of these firms were obtained and the content analysis was carried out. In non-probability sampling, the sampling units do not have an equal opportunity of being included in the sample. This is because the researcher purposely chooses sample units from the sample frame (Etikan \& Bala 2017:1).

The sample consisted of the top nine audit firms in South Africa, as determined by the IRBA (2020:n.p.):

1. PricewaterhouseCoopers.

2. Deloitte and Touche.

3. KPMG.

4. Ernst and Young.

5. Binder Dijker Otte (BDO) South Africa.

6. Mazars

7. SizweNtsalubaGobodo Grant Thornton.

8. A2A Kopano.

9. $\mathrm{SAB}$ and $\mathrm{T}$ Chartered Accountants, trading as Nexia SAB \& $\mathrm{T}$
As mentioned earlier, the data were sourced from the transparency reports of these audit firms. In cases where such a report was unavailable on the website of the audit firm, the researcher sent the firm an email asking for a report. The 20182019 reports were the most recent available given that some of the 2020 reports were only published after this study was completed. These transparency reports were read, analysed and compared with the checklist criteria. As there were only nine firms in the sample, the researchers were able to conduct the content analysis by reading each report in depth.

To ensure data quality and integrity, an auditing method was followed. This included maintaining comprehensive records for all phases of the study (Bryman \& Bell 2007). Independent individuals were also used to verify that the analysis was a fair reflection of the content conveyed in the audit firms' transparency reports. As the sample was small and all the audit firms complied with the same regulations, external validity was ensured. The researchers remained impartial and neutral throughout the research process in this study. Ethical approval was granted by the University of Johannesburg and every effort was made to ensure the integrity of the data and preserve the confidentiality of individual recipient data.

\section{Findings and analysis}

The section presents the qualitative findings obtained through the content analysis of the transparency reports of the top nine audit firms in South Africa. Only seven of the audit firms published transparency reports; thus, the sample used in the content analysis consisted of these seven firms.

\section{Publication of transparency reports}

According to the literature, the publication of transparency reports is not yet compulsory in South Africa, although it is recommended by the IRBA (2018). Accordingly, the first objective of the analysis was to determine whether the firm had published a transparency report.

As can be seen in Table 1, seven of the audit firms published transparency reports. It was pleasing to note that the majority of the audit firms issued transparency reports on an annual basis. This could be an indication that they were aware of the call from the IRBA to issue such reports and that they were already preparing themselves for the eventuality of these reports becoming compulsory in the future. However, it was concerning that one of the firms that had failed to issue a TR was regarded as one of the bigger audit firms in South Africa. The other firm that did not issue a report was a smaller medium-sized firm. Both these firms did, however, indicate that they planned to issue a TR in the near future. This finding may be an indication that audit firms need guidance, through a formalised corporate governance code, stating what

TABLE 1: Release of transparency or integrated reports.

\begin{tabular}{lcccccc}
\hline Reports & Yes & $\mathbf{\%}$ & No & $\mathbf{\%}$ & Total & Total \% \\
\hline Transparency report & 7 & 77.80 & 2 & 22.2 & 9 & 100 \\
Integrated report & 2 & 22.20 & 7 & 77.8 & 9 & 100 \\
\hline
\end{tabular}


information should be included in these reports. Such a code would also ensure consistency across firms.

In the following sections, the findings of the content analysis are discussed according to the six principles of the UK Audit Firm Governance Code.

\section{Leadership}

\section{Objective}

According to the FRC (2016), the objective of the leadership principle is for audit firms to display effective management, with responsibility and clear authority for running the firm. This principle also expects the management of a firm to be accountable to the firm's owners, with no individual holding unfettered powers of decision (FRC 2016).

\section{Findings}

Table 2 first indicates the platform used to publish the transparency reports. Four audit firms published their transparency reports on their websites whilst three had to be requested via email. The analysis of the reports revealed that seven of the audit firms disclosed information about an EXCO, whilst only two disclosed information about an oversight board.

Table 2 also presents information disclosed on the EXCO. Two firms disclosed the duties of their EXCO members, whilst one firm disclosed the decisions that were made by the EXCO members. Three audit firms disclosed the job titles of their EXCO members. One firm disclosed information about the election and appointment of its EXCO members and one firm disclosed the terms of its

TABLE 2: Findings on the leadership principles.

\begin{tabular}{|c|c|c|c|c|c|c|}
\hline Leadership & Yes & $\%$ & No & $\%$ & Total & Total \% \\
\hline \multicolumn{7}{|c|}{ Leadership disclosure in the transparency report } \\
\hline Available on the website & 4 & 57.14 & 3 & 42.86 & 7 & 100 \\
\hline $\begin{array}{l}\text { EXCO information disclosed in } \\
\text { transparency report }\end{array}$ & 7 & 100 & 0 & 0 & 7 & 100 \\
\hline $\begin{array}{l}\text { Oversight board information } \\
\text { disclosed in transparency report }\end{array}$ & 2 & 28.57 & 5 & 71.43 & 7 & 100 \\
\hline \multicolumn{7}{|c|}{ Disclosure about the EXCO in the transparency report } \\
\hline Duties & 2 & 28.57 & 5 & 71.43 & 7 & 100 \\
\hline Decisions made & 1 & 14.29 & 6 & 85.71 & 7 & 100 \\
\hline Job titles & 3 & 42.86 & 4 & 57.14 & 7 & 100 \\
\hline Election and appointment & 1 & 14.29 & 6 & 85.71 & 7 & 100 \\
\hline Terms & 1 & 14.29 & 6 & 85.71 & 7 & 100 \\
\hline Length of service & 2 & 28.57 & 5 & 71.43 & 7 & 100 \\
\hline Meeting attendance & 0 & 0 & 7 & 100 & 7 & 100 \\
\hline Biographical details & 0 & 0 & 7 & 100 & 7 & 100 \\
\hline \multicolumn{7}{|c|}{ Disclosure about the oversight board in the transparency report } \\
\hline Duties & 2 & 28.57 & 5 & 71.43 & 7 & 100 \\
\hline Decisions made & 2 & 28.57 & 5 & 71.43 & 7 & 100 \\
\hline Job titles & 3 & 42.86 & 4 & 57.14 & 7 & 100 \\
\hline Election and appointment & 1 & 14.29 & 6 & 85.71 & 7 & 100 \\
\hline Terms & 1 & 14.29 & 6 & 85.71 & 7 & 100 \\
\hline Length of service & 2 & 28.57 & 5 & 71.43 & 7 & 100 \\
\hline Meeting attendance & 1 & 14.29 & 6 & 85.71 & 7 & 100 \\
\hline Biographical details & 1 & 14.29 & 6 & 85.71 & 7 & 100 \\
\hline
\end{tabular}

EXCO, Executive committee.
EXCO members. Only two firms disclosed information about the length of service. None of the firms disclosed information about meeting attendance or any biographical details of their EXCO members.

Lastly, Table 2 presents the information disclosed by the audit firms about oversight boards. Two firms disclosed the duties of their oversight board members whilst two firms disclosed the decisions that were made by the board. Three firms disclosed the job titles of their oversight board members, one firm disclosed information about election and appointment of board members and one firm disclosed the terms of its board members. Two firms disclosed information about length of service whilst only one firm disclosed information about meeting attendance and the biographical details of its oversight board members.

\section{Literature and deduction}

From the given discussion, it can be deduced that all audit firms appointed an EXCO and disclosed information about the EXCO in their transparency reports. The EXCO refers to the executive committee of the audit firm and the members are selected from the partners of the firm. According to the APA, a partner must be a qualified chartered accountant (CA [SA]) and registered with the South African Institute of Chartered Accountants (SAICA) and the IRBA (Deloitte 2019:9). The appointment of INEDs to the EXCO can be challenging; very few audit firms (only two) disclosed information about their oversight board. Independent non-executive directors are appointed to the oversight board, which ensures oversight and governance of the firm. As a result of the difficulty of appointing INEDs in audit firms, it is concluded that few firms have appointed these independent boards. This could also be an indication that the audit firms are waiting for reform in terms of the APA and additional guidance on how to appoint and implement more independent members in the firms.

The given findings suggest that more guidance is necessary for audit firms on leadership disclosure in the transparency reports. The firms disclosed minimal information about their EXCO and oversight board and there were inconsistencies between firms in the information that was disclosed. This makes it difficult for the users of reports, as there is no standardisation of information that should be disclosed. Once again, it seems that audit firms are willing to disclose information about their EXCO and oversight boards, but the lack of structure creates uncertainty as to exactly what should be included in the transparency reports.

\section{Values \\ Objective}

The objective of the value principle, according to the FRC (2016), is for audit companies to produce high-quality work by exercising judgement and maintaining integrity, objectivity, confidentiality and due care. They should use 
their professional competence and conduct in a way that considers the public interest and adheres to auditing and ethical standards. In order to do quality work, a company should have an open culture that encourages workers to consult and share problems, expertise and experience (FRC 2016).

\section{Findings}

Table 3 shows that five audit firms disclosed their code of conduct and indicated to whom the code of conduct was applicable.

\section{Literature and deduction}

The findings illustrate that audit firms do disclose information about their codes of conduct and the values that govern them. However, the concerns stem from the application of these values. As a result of the lack of a formal corporate governance code for audit firms, these values differ from one firm to another, thereby creating inconsistencies. Once again, it is submitted that the values that govern the audit firms should be formalised through specific guidelines or a corporate governance code for audit firms.

\section{Independent non-executive directors \\ Objective}

According to the FRC (2016), a firm should appoint INEDs to its governance structure. Their involvement should contribute to the firm's efforts to meet the principles of a corporate governance code. The INEDs' duty of care is to the firm (FRC 2016). The principles in the UK Code that deal with INEDs were analysed through the checklist to establish whether they were already being applied by South African audit firms. The reader is reminded that the study focuses on South African governance structures; consequently, global oversight boards were not analysed.

Table 4 presents the information that the audit firms disclosed about their INEDs. The principle of INEDs consists of separate provisions, namely the involvement of INEDs, disclosure of INEDs, characteristics of INEDs and the rights and responsibilities of INEDs. Table 4 has been divided according to these provisions to ensure that the information is displayed in a coherent manner.

\section{Findings}

Table 4 shows that none of the audit firms had an oversight board that consisted of a majority of INEDs. Two of the audit firms appointed at least three INEDs to their oversight boards. The five audit firms that did not have at least three

\begin{tabular}{|c|c|c|c|c|c|c|}
\hline Values & Yes & $\%$ & No & $\%$ & Total & Total \% \\
\hline $\begin{array}{l}\text { Code of conduct on } \\
\text { website }\end{array}$ & 5 & 71.43 & 2 & 28.57 & 7 & 100 \\
\hline $\begin{array}{l}\text { Discloses to whom the } \\
\text { code of conduct is } \\
\text { applicable }\end{array}$ & 5 & 71.43 & 2 & 28.57 & 7 & 100 \\
\hline
\end{tabular}

INEDs did not disclose why this was so. Only two of the audit firms had a majority of INEDs who were members of other relevant governance structures of the firm.

As can be seen in Table 4, only one of the audit firms disclosed the appointment, retirement, resignation, remuneration and duties of its INEDs, how the INEDs discharged their duties and how the firm supported the INEDs in this regard. The table indicates that three of the audit firms disclosed how they positioned their INEDs within the firm.

Furthermore, Table 4 reveals that two of the audit firms had INEDs on their oversight boards with skills and experience in audit and who were competent in the field of auditing and accounting. Only one firm disclosed how its INEDs contributed to its independence. None of the firms disclosed information on the rights and responsibilities on INEDs or on procedures for dealing with any fundamental disagreement.

\section{Literature and deduction}

According to SAAPTI (2020:49), South African audit firms should improve their governance structures through the appointment of an independent oversight board. Such a board would be chiefly concerned with the governance and oversight of the executive management and the audit firm. Nkuhlu (2020) strongly recommended that audit firms should appoint INEDs to provide more effective oversight.

The findings presented in Table 4 indicate that very few audit firms have established oversight boards. As stated earlier, only two firms have such boards, and of these, it seems that only one firm has implemented some of the INED principles and provisions, as stipulated in the UK Audit Firm

TABLE 4: Findings on the independent non-executive director principle.

\begin{tabular}{|c|c|c|c|c|c|c|}
\hline Variable & Yes & $\%$ & No & $\%$ & Total & Total \% \\
\hline \multicolumn{7}{|l|}{ Involvement of INEDs } \\
\hline Consists of a majority of INEDs & 0 & 0 & 7 & 100 & 7 & 100 \\
\hline Has at least three INEDs & 2 & 28.57 & 5 & 71.43 & 7 & 100 \\
\hline $\begin{array}{l}\text { Discloses reasons for not having at } \\
\text { least three INEDs }\end{array}$ & 0 & 0 & 7 & 100 & 7 & 100 \\
\hline $\begin{array}{l}\text { Has a majority of INEDs who are } \\
\text { members of other relevant } \\
\text { governance structures in the firm }\end{array}$ & 2 & 28.57 & 5 & 71.43 & 7 & 100 \\
\hline \multicolumn{7}{|l|}{ Disclosure about the INEDs } \\
\hline $\begin{array}{l}\text { Appointment, retirement and } \\
\text { resignation of INEDs }\end{array}$ & 1 & 14.29 & 6 & 85.7 & 7 & 100 \\
\hline Remuneration of INEDs & 1 & 14.29 & 6 & 85.71 & 7 & 100 \\
\hline Duties of INEDs & 1 & 14.29 & 6 & 85.71 & 7 & 100 \\
\hline INEDs' discharge of duties & 1 & 14.29 & 6 & 85.71 & 7 & 100 \\
\hline Firm support for INEDs & 1 & 14.29 & 6 & 85.7 & 7 & 100 \\
\hline How the firm positions INEDs & 3 & 42.86 & 4 & 57.14 & 7 & 100 \\
\hline \multicolumn{7}{|l|}{ Characteristics of INEDs } \\
\hline $\begin{array}{l}\text { Has INEDs who have skills and } \\
\text { experience in audit }\end{array}$ & 2 & 28.57 & 5 & 71.43 & 7 & 100 \\
\hline $\begin{array}{l}\text { Has INEDs who are competent in } \\
\text { auditing/accounting }\end{array}$ & 2 & 28.57 & 5 & 71.43 & 7 & 100 \\
\hline How INEDs influence independence & 1 & 14.29 & 6 & 85.7 & 7 & 100 \\
\hline \multicolumn{7}{|l|}{ Rights and responsibilities of INEDs } \\
\hline $\begin{array}{l}\text { Discloses the procedures for dealing } \\
\text { with any fundamental disagreements }\end{array}$ & 0 & 0 & 7 & 100 & 7 & 100 \\
\hline
\end{tabular}

INEDs, Independent non-executive directors. 
Governance Code. The lack of independence and independent oversight of audit firms is concerning. This is a definitive area that should be addressed by all large- and mediumsized audit firms.

\section{Operations}

\section{Objective}

According to the FRC (2016), the objective of the operations principle is that a firm should comply with professional standards and applicable legal and regulatory requirements.

\section{Findings}

Table 5 presents the information disclosed by audit firms on their operations. Four of the firms provided details of policies and procedures to manage conflicts of interest. Only two firms disclosed information about the effectiveness of their internal control systems and the process followed to review the effectiveness of internal control systems. Moreover, only two firms disclosed the weaknesses identified in their internal control systems and the actions taken to address those weaknesses. One firm disclosed how it supported its commitment to professionalism, openness and risk management. Six of the firms disclosed information about their whistle-blowing policies and procedures.

\section{Literature and deduction}

The findings reveal that most of the operations principles were not disclosed by the majority of the audit firms. This is concerning given that audit firms should disclose to the public and all stakeholders how their risks are managed and whether their internal controls are effective. As audit firms largely serve the public interest, it is important that they maintain transparency in their disclosure about risks and internal controls.

It should be noticed that one audit firm did disclose all the operations principles in its integrated report (IR) but not in its transparency report. This was, therefore, included in the findings as a 'Yes'.

TABLE 5: Findings on the operations principle.

\begin{tabular}{|c|c|c|c|c|c|c|}
\hline Operations & Yes & $\%$ & No & $\%$ & Total & $\overline{\text { Total }(\%)}$ \\
\hline $\begin{array}{l}\text { Policies and procedures } \\
\text { to manage conflicts of } \\
\text { interest }\end{array}$ & 4 & 57.14 & 3 & 42.86 & 7 & 100 \\
\hline $\begin{array}{l}\text { Effectiveness of the } \\
\text { internal control system }\end{array}$ & 2 & 28.57 & 5 & 71.43 & 7 & 100 \\
\hline $\begin{array}{l}\text { Process followed in } \\
\text { reviews }\end{array}$ & 2 & 28.57 & 5 & 71.43 & 7 & 100 \\
\hline $\begin{array}{l}\text { Weaknesses in internal } \\
\text { control system }\end{array}$ & 2 & 28.57 & 5 & 71.43 & 7 & 100 \\
\hline $\begin{array}{l}\text { Actions to address } \\
\text { weaknesses }\end{array}$ & 2 & 28.57 & 5 & 71.43 & 7 & 100 \\
\hline $\begin{array}{l}\text { How the firm supports its } \\
\text { commitment to } \\
\text { professionalism, openness } \\
\text { and risk management }\end{array}$ & 1 & 14.29 & 6 & 85.71 & 7 & 100 \\
\hline $\begin{array}{l}\text { Whistle-blowing policies } \\
\text { and procedures }\end{array}$ & 6 & 85.71 & 1 & 14.29 & 7 & 100 \\
\hline
\end{tabular}

\section{Reporting}

\section{Objective}

The objective of the reporting principle in the UK Audit Firm Governance Code, according to the FRC (2016), is for a firm's management to ensure that members of its governance structures, such as owners and INEDs, are provided with information in a timely manner, in a form and of a quality that allows them to discharge their duties. Moreover, this principle requires audit firms to report on their compliance and non-compliance with the applicable governance code. In their annual transparency reports, firms should also include a comment on their performance, position and aspirations.

\section{Findings}

Table 6 presents the information that the audit firms disclosed about their reporting. This refers to the way in which the information was conveyed to the public, the committees that the audit firms reported on and the publication of audited financial statements.

Only three of the audit firms included commentary on the firm's performance, position and prospects. Four firms included information that was fair and balanced. Six of the firms conveyed information in an understandable manner.

With reference to committees, three of the audit firms disclosed information about having an audit committee, five disclosed information about having a risk committee and two disclosed information about a nomination committee. Three of the firms disclosed information about a remuneration committee and two firms had ethics committees. Only one firm indicated that its audit committee was constituted according to the principles of King IV.

TABLE 6: Findings on the reporting principle.

\begin{tabular}{|c|c|c|c|c|c|c|}
\hline Reporting & Yes & $\%$ & No & $\%$ & Total & Total (\%) \\
\hline $\begin{array}{l}\text { Includes a commentary on } \\
\text { the firm's performance, } \\
\text { position and prospects }\end{array}$ & 3 & 42.86 & 4 & 57.14 & 7 & 100 \\
\hline $\begin{array}{l}\text { Includes fair and balanced } \\
\text { information }\end{array}$ & 4 & 57.14 & 3 & 42.86 & 7 & 100 \\
\hline $\begin{array}{l}\text { Explains everything in an } \\
\text { understandable manner }\end{array}$ & 6 & 85.71 & 1 & 14.29 & 7 & 100 \\
\hline Has an audit committee & 3 & 42.86 & 4 & 57.14 & 7 & 100 \\
\hline Has a risk committee & 5 & 71.43 & 2 & 28.57 & 7 & 100 \\
\hline $\begin{array}{l}\text { Has a nomination } \\
\text { committee }\end{array}$ & 2 & 28.57 & 5 & 71.43 & 7 & 100 \\
\hline $\begin{array}{l}\text { Has a remuneration } \\
\text { committee }\end{array}$ & 3 & 42.86 & 4 & 57.14 & 7 & 100 \\
\hline Has an ethics committee & 2 & 28.57 & 5 & 71.43 & 7 & 100 \\
\hline $\begin{array}{l}\text { Audit committee } \\
\text { constituted according to } \\
\text { King IV }\end{array}$ & 1 & 14.29 & 6 & 85.71 & 7 & 100 \\
\hline $\begin{array}{l}\text { Publishes audited financial } \\
\text { statements }\end{array}$ & 0 & 0 & 7 & 100 & 7 & 100 \\
\hline $\begin{array}{l}\text { Publishes audited financial } \\
\text { statements prepared with } \\
\text { the financial reporting } \\
\text { framework }\end{array}$ & 0 & 0 & 7 & 100 & 7 & 100 \\
\hline $\begin{array}{l}\text { Publishes audited financial } \\
\text { statements that are clear } \\
\text { and concise }\end{array}$ & 0 & 0 & 7 & 100 & 7 & 100 \\
\hline $\begin{array}{l}\text { Explains who is responsible } \\
\text { for preparing the financial } \\
\text { statements }\end{array}$ & 0 & 0 & 7 & 100 & 7 & 100 \\
\hline
\end{tabular}


Evidence was neither found of published audited financial statements nor was there any information regarding the reporting framework or who was responsible for preparing the financial statements. None of the firms disclosed that their financial statements were clear and concise. A further search was performed to determine whether the audited financial statements were possibly published on other platforms; however, no such evidence was found.

\section{Literature and deduction}

As stated by the IoDSA (2016), transparency is a core element of corporate governance. According to the FRC (2019), it is critical for investors to assess the governance approach applied in an audit firm. Reporting on governance would cover the implementation of the principles of the relevant code with regard to the company's specific circumstances, how the board defined the mission and strategy of the company, reached targets and achieved results through its decisions (FRC 2019). In addition to providing stakeholder information, reporting promotes transparency and ensures that leadership does, in fact, reflect the primary governance and performance concerns it is intended to address (FRC 2016).

The findings reveal that only two of the provisions were implemented by the majority of the audit firms. In this study, the conclusions on the understandability of the information in the reports could be subjective. The assessment was based merely on the opinion of the researcher and each user of the transparency reports of the audit firms may have a different opinion. Once again, this could stem from the lack of specific guidelines for audit firms, explaining what information should be included in transparency reports and which committees should be established.

The fact that none of the audit firms published audited financial statements is also a concern. The public, whose interests these firms serve, has no insight into the financial information of these firms. This too, is something that could be addressed through formal guidelines for audit firms.

\section{Dialogue}

\section{Objective}

The UK Audit Firm Governance Code's dialogue principle, according to the FRC (2016), aims to ensure that audit firms participate in discussion with listed company shareholders and listed companies and their audit committees. The goal is to improve mutual communication and understanding so that the company is aware of shareholder concerns, issues and opinions.

\section{Findings}

Table 7 presents the information that the audit firms disclosed on dialogue. Three firms disclosed policies and procedures for dialogue with listed company shareholders and listed companies. Only one firm disclosed the nature and extent of the involvement of the INEDs in the dialogue.

\section{Literature and deduction}

It is evident that most audit firms failed to disclose appropriate information on the dialogue principle. The literature states that governance includes communication and involvement with shareholders and stakeholders. It is thus important that audit firms have regular dialogue with these parties and disclose the relevant information in their transparency reports.

Table 8 shows a summary of the findings for each principle. The table indicates whether the audit firms disclosed more or less than $50 \%$ of the required principles in their reports.

\section{Conclusion and recommendations}

The study determined which of the disclosure principles and provisions contained in the UK Audit Firm Governance Code were disclosed by South African audit firms in their transparency reports.

According to the literature, audit firms are expected to reveal any information that would promote market trust and increase transparency (Kumar \& Zattoni 2014:3; Mallin 2002; OECD 2015). According to the IRBA (2018), releasing a TR informs the public about many aspects of the firm and its operations. The IAASB (2014) reiterates this, stating that audit firm transparency reports help third parties - such as the general public and users of audited financial statements - understand the characteristics of the specific audit company and the drivers of audit quality in the business. Transparency reports, according to La Rosa et al. (2018:30), give useful information on audit firm quality and impartiality.

The call for greater transparency and disclosure by audit firms is validated by the recent high-profile audit firm failures and the lack of confidence in the financial market in the post-global financial crisis era (Huddart 2013:390). This is supported by IRBA, which recommends that all audit firms issue a TR (IRBA 2018). Although not yet compulsory, this practice is expected to become compulsory in the near future.

TABLE 7: Findings on the dialogue principle.

\begin{tabular}{lcccccc}
\hline Dialogue & Yes & $\mathbf{\%}$ & No & \% & Total & Total (\%) \\
\hline $\begin{array}{l}\text { Discloses policies and } \\
\text { procedures for dialogue }\end{array}$ & 3 & 42.86 & 4 & 57.14 & 7 & 100 \\
$\begin{array}{l}\text { with listed company } \\
\text { shareholders and listed } \\
\text { companies }\end{array}$ & & & & & & \\
$\begin{array}{l}\text { Discloses the nature and } \\
\text { extent of the involvement } \\
\text { of INEDs in the dialogue }\end{array}$ & 1 & 14.29 & 6 & 85.71 & 7 & 100 \\
\hline
\end{tabular}

TABLE 8: Summary of findings.

\begin{tabular}{lc}
\hline Principle as per the UK audit firm governance code & Disclosure \% \\
\hline Leadership & $<50$ \\
Values & $>50$ \\
INEDs & $<50$ \\
Operations & $<50$ \\
Reporting & $<50$ \\
Dialogue & $<50$ \\
\hline
\end{tabular}

INED, Independent non-executive directors; UK, United Kingdom. 
The findings of this study revealed that the disclosure of corporate governance information in the transparency reports did not always contain sufficient details. This lack of disclosure reduces the reliance of stakeholders on the corporate governance of the audit firms, thereby undermining public trust in the profession. The minimal disclosure by audit firms suggests that the firms may be unaware of the information that should be disclosed in their transparency reports. Consequently, there is a strong need for guidelines on the disclosure that is expected of audit firms. Formal guidelines or a code would ensure that audit firms disclose necessary and consistent information to the public.

A shortcoming of the South Africa's corporate governance code, King IV, is that it does not contain any sector supplements for audit firms. Thus, the application of King IV as it currently stands is challenging for audit firms. It would be difficult for firms to apply all the principles in King IV, especially those relating to the appointment of INEDs. This is because the APA also makes it impossible for audit firms to appoint INEDs to their EXCO; therefore, reform of this act would be necessary.

Six recommendations are proposed based on the findings of this study:

1. The IoDSA should consider the inclusion of a sector supplement for audit firms in future King Code iterations.

2. The IRBA should consider using the findings of this study and the UK Audit Firm Governance Code to draft guidelines for audit firms on corporate governance.

3. An amendment of the APA should be considered to facilitate the appointment of INEDs for audit firms.

4. Professional bodies and institutions such as the IoDSA and SAAPTI should consider providing best practice standards on corporate governance at audit firms.

5. The IoDSA (or the IRBA, as the regulator) should consider providing a statement for audit firms, giving them guidance on corporate governance practices (such as the UK Audit Firm Governance Code provided by the FRC).

6. All audit firms should give greater consideration to the practice of good corporate governance to enjoy the benefits that it offers. As the principles embodied in King IV are similar to those contained in the UK Audit Firm Governance Code, the audit firms could start by implementing the relevant principles of King IV until more specific developments emerge in future.

Based on the study's findings, it can be concluded that that the application of corporate governance in large- and mediumsized audit firms is inadequate. This was evident from the empirical results and the content analysis. The key reason for the low levels of corporate governance in South African audit firms is attributed to the lack of a South African corporate governance code specifically designed for audit firms.

The following step-by-step approach could be used by the IRBA and professional bodies to improve corporate governance implementation and disclosure at audit firms.

\section{Acknowledgements Competing interests}

The authors declare that they have no financial or personal relationships that may have inappropriately influenced them in writing this article.

\section{Authors' contributions}

R.J.S. performed the literature review and content analysis. Prof. B.M. supervised the study.

\section{Ethical considerations}

This article followed all ethical standards for research without direct contact with human or animal subjects.

\section{Funding information}

This research received no specific grant from any funding agency in the public, commercial or not-for-profit sectors.

\section{Data availability}

Data sharing is not applicable to this article as no new data were created or analysed in this study.

\section{Disclaimer}

The views and opinions expressed in this article are those of the authors and do not necessarily reflect the official policy or position of any affiliated agency of the author.

\section{References}

Abedian, I., 2019, 'Audit profession needs a new dawn', Daily Maverick, 19 March, viewed 15 October 2018, from https://www.dailymaverick.co.za/ opinionista/2018-03-19-audit-profession-needs-a-new-dawn.

Amirul, S.M., Salleh, M.F. \& Abu Bakar, M.A.A.B., 2015, 'Audit firm governance: An overview from Malaysia' in proceedings of the International accounting and business conference 2015, Procedia, Economics and Finance, viewed 17 September 2019, from https://www.sciencedirect.com/science/article/pii/ S221256711501151X.

Bauwhede, V.H. \& Willekens, M., 2008, 'Disclosure on corporate governance in the European Union', Corporate Governance: An International Review 16(2), 101-115. https://doi.org/10.1111/j.1467-8683.2008.00671.x

Bowker, J., Bonorchis, R. \& Wild, F., 2017, 'Why Steinhoff could be next Enron' Moneyweb and Bloomberg, 19 December, viewed 15 October 2018, from https:// www.moneyweb.co.za/news/companies-and-deals/why-steinhoff-could-benext-enron/.

Brydon, D., 2019, Report of the independent review into the quality and effectiveness of audit, Crown, London.

Bryman, A. \& Bell, E., 2007, Business research methods, 3rd edn., Oxford University Press.

Cavanagh, S., 1997, 'Content analysis: Concepts, methods and applications', Nurse Researcher 4(3), 5-16. https://doi.org/10.7748/nr.4.3.5.s2

Cohen, L. \& Manion, L., 1994, Research methods in education, 4th edn., Routledge, London.

Cole, F.L., 1988, 'Content analysis: Process and application', Clinical Nurse Specialist 2(1), 53-57. https://doi.org/10.1097/00002800-198800210-00025

Collett, P. \& Hrasky, S., 2005, 'Voluntary disclosure of corporate goernance practices by listed Australian companies', Corporate Governance: An International Review 13(2), 188-196. https://doi.org/10.1111/j.1467-8683.2005.00417.x

Cotterill, J., 2017, 'KPMG South Africa executives dismissed over Gupta scandal', viewed 15 October 2018, from https://www.ft.com/content/ce8ddb84-9a01 11e7-a652-cde3f882dd7b.

Creswell, J.W., 2003, Research design: Qualitative, quantitative and mixed methods approaches, 2 nd edn., Sage, Thousand Oaks, CA.

Crotty, A., 2019, 'Who broke auditing ... and can it be fixed?', Financial Mail, 08 August, viewed 30 August 2019, from www.financialmail.co.za. 
Deloitte, 2019, 2019 Transparency report, viewed 23 August 2020, from https:// www2.deloitte.com/za/en/services/centre-for-corporate-governance/ wWw2.deloitte.com $/$ za/en
integrated-reporting.html.

Deumes, R., Schelleman, C., Bauwhede, H.V. \& Vanstraelen, A., 2012, 'Audit firm governance: Do transparency reports reveal audit quality?', Auditing: A Journal of Practice and Theory 31(4), 193-214. https://doi.org/10.2308/ajpt-10301

Downe-Wamboldt, B., 1992, 'Content analysis: Method, applications and issues', Health Care for Women International 13(3), 313-321. https://doi. org/10.1080/07399339209516006

Etikan, I. \& Bala, K., 2017, 'Sampling and sampling methods', Biometrics \& Biostatistics International Journal 5(6), 5-7. https://doi.org/10.15406/bbij.2017.05.00149

Financial Reporting Council (FRC), 2010, The audit firm governance code, FRC.

Financial Reporting Council (FRC), 2016, Audit firm governance code revised 2016 viewed 02 January 2020, from https://www.frc.org.uk/Our-Work/Publications/ FRC-Board/Audit-Firm-Governance-Code-Revised-2016.pdf.

Financial Reporting Council (FRC), 2019, The UK stewardship report, viewed from https://www.frc.org.uk/getattachment/5aae591d-d9d3-4cf4-814ad14e156a1d87/Stewardship-Code_Final2.pdf.

Frederick, R., 2000, 'Disclosure: A coporate governance tool that really works?', in proceedings of the third meeting of the Russian corporate governance roundtable, viewed 13 January 2020, from https://www.oecd.org/corporate/ca/corporatego viewed 13 January 2020, from $\mathrm{h}$

Fung, B., 2014, 'The demand and need for transparency and disclosure in corporate governance', Universal Journal of Management 2(2), 72-80. https://doi. org/10.13189/ujm.2014.020203

Fu, Y.D., Carson, E. \& Simnett, R., 2015, 'Transparency report disclosure by Australian audit firms and opportunities for research', Managerial Auditing Journal 30(8/9), 870-910. https://doi.org/10.1108/MAJ-06-2015-1201

Harber, M., 2018, 'Mandatory audit firm rotation: A South African perspecitve', PhD thesis, University of Johannesburg.

Hosken, G., 2017, 'KPMG cans SARS “rogue unit” report, apologies to Gordhan', Times Live, 15 September, viewed 15 October 2018, from https://www.timeslive.co.za/ politics/2017-09-15-kpmg-cans-sars-rogue-unit-report-apologises-to-gordhan/.

Huddart, S., 2013, 'Discussion of empirical evidence on the implicit determinants of compensation in Big 4 audit partnerships', Journal of Accounting Research 51(2), 389-397. https://doi.org/10.1111/1475-679X.12010

Independent Regulatory Board for Auditors (IRBA), 2017, IRBA newsletter 37, IRBA.

Independent Regulatory Board for Auditors (IRBA), 2018, Transparency reports will strengthen confidence in audit firms, IRBA, Johannesburg.

Independent Regulatory Board for Auditors (IRBA), 2019, Annual report 2019/2020 viewed 07 August 2020, from https://www.irba.co.za/upload/Annual\%20 Report $\% 202019 \% 20$ Final.pdf.

Independent Regulatory Board for Auditors (IRBA), (cgarbutt@irba.co.za), 26 Augus 2020, List of audit firms with 20+ partners, email sent to Rozanne Smith (rozannes@uj.ac.za).

Institute of Directors in Southern Africa (IoDSA), 2016, King IV report on corporate governance for South Africa, viewed 12 October 2018, from https://cdn.ymaws. E3A007F15A5A/IoDSA_King_IV_Report_-_WebVersion.pdf.
International Auditing and Assurance Standards Board (IAASB), 2014, Handbook of international quality control, auditing, review, other assurance and related services pronouncements, IAASB, New York, NY.

Kumar, P. \& Zattoni, A., 2014, 'Corporate governance, information and investor confidence', Corporate Governance: An International Review 22(6), 437-439. https://doi.org/10.1111/corg.12094

La Rosa, F., Caserio, C. \& Bernini, F., 2018, 'Corporate governance of audit firms: Assessing the usefulness of transparency reports in a Europe-wide analysis', Corporate Governance: An International Review 27(1), 14-32. https://doi. org/10.1111/corg.12235

Mackenzie, N. \& Knipe, S., 2006, 'Research paradigms, methods and methodology', Issues in Educational Research 16(3), 213-231.

Mallin, C., 2002, 'The relationship between corporate governance, transparency and financial disclosure', Corporate Governance: An International Review 10(4), 253-255. https://doi.org/10.1111/1467-8683.00289

Mangena, M. \& Chamisa, E., 2008, 'Corporate governance and incidences of listing suspension by the JSE securities exchange of South Africa: An empirical analysis', International Journal of Accounting 43(1), 28-44. https://doi.org/10.1016/j. intacc.2008.01.002

Markarian, G., Parbonetti, A. \& Previts, G.J., 2007, 'The convergence of disclosure and governance practices in the world's largest firms', Corporate Governance: An International Review 15(2), 294-310. https://doi.org/10.1111/j.1467-8683. 2007.00561.x

Mertens, D.M., 2005, Research methods in education and psychology: Integrating diversity with quantitative and qualitative approaches, 2 nd edn., Sage, Thousand Oaks, CA.

Nkuhlu, W.L., 2020, 'State capture: KPMG's slippery slide', Sunday Times, 04 October [In print].

Organisation for Economic Co-operation and Development (OECD), 2015, G20/OECD principles on corporate governance, OECD, Paris.

Patel, M.R., 2013, 'Transparency and accountability in governance as reforming tools in India', Voice of Research 2(2), 56-60, viewed 15 January 2020, from http:// www.voiceofresearch.org/doc/Sep-2013/Sep-2013_13.pdf.

Pilling, D., 2017, 'KPMG urged to act over South Africa Gupta scandal', viewed 15 October 2018, from https://www.ft.com/content/c525699e-a6a5-11e7-ab5527219 df83c97.

Shoaib, A., 2017, 'KPMG rocked by South African corruption scandal', Accountancy Age, 27 September, viewed 15 October 2018, from https://www.accountancyage. com/2017/09/27/kpmg-rocked-south-african-corruption-scandal/.

Sikka, P., 2003, 'Some questions about the governance of audit firms', International Journal of Disclosure and Governance 1(2), 186-199. https://doi.org/10.1057/ palgrave.jdg.2040023

South African Auditing Profession Trust Initiative (SAAPTI), 2020, Discussion document Considerations to address the key challenges facing the South African auditing profession, SAAPTI.

Teck-Heang, L.E.E. \& Ali, A.M., 2008, 'The evolution of auditing: An analysis of the historical development', Journal of Modern Accounting and Auditing 4(12), $1-8$. 


\section{Appendix 1}

TABLE 1-A1: Checklist used for the empirical study.

Control sheet for the analysis of the transparency reports

Name of the company or firm: (This will only be used should additional information be required after the completion of the questionnaire. The names of the auditing firm will not be made public in the research and all information will be treated as confidential and only reported on in aggregate).

Comments:

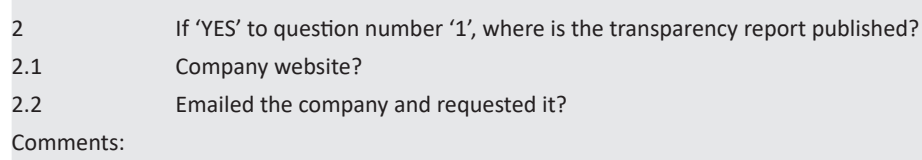

Comments:

Does the auditing firm issue an integrated report?

With regard to the composition of the Board of Directors, what information is disclosed on the composition of the Board of Directors?

Number of members

Number of executive directors

Number of non-executive directors

Number of INED directors

Race (number of members)

a. Black

b. Mixed race

c. Indian

d. White 
Comments:

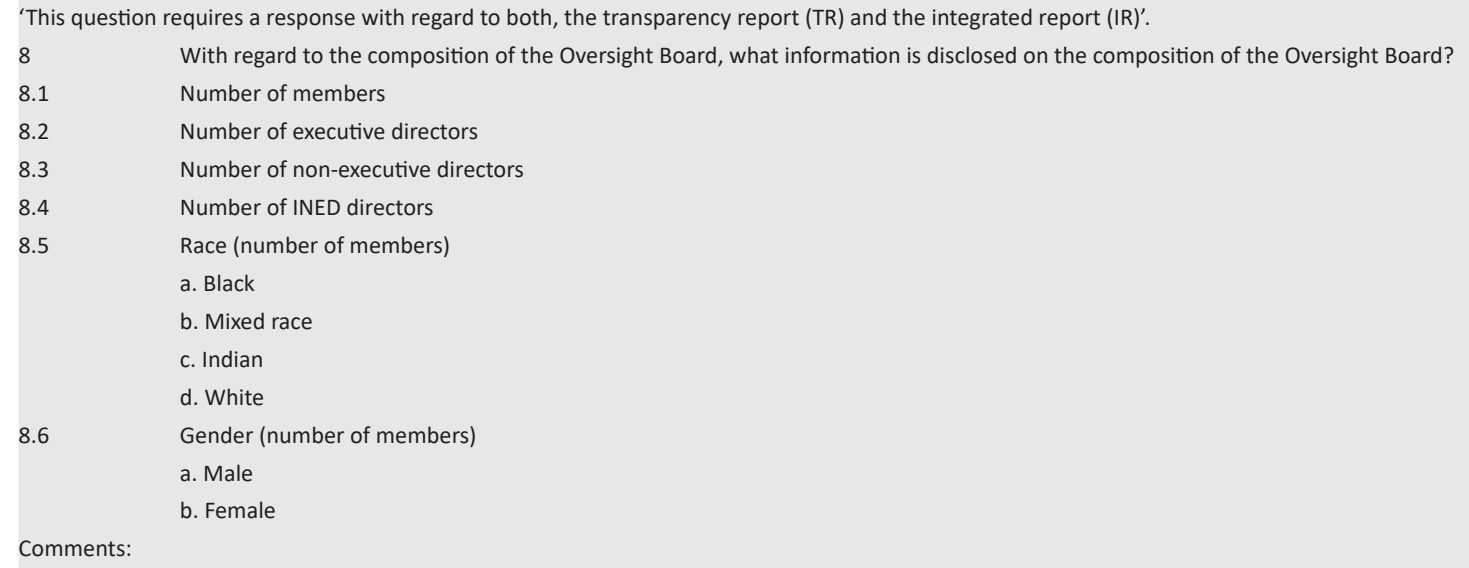

Comments:

9 From the information disclosed on the Board of Directors, does the Board of Directors consist of:

9.1 A majority of INED directors?

$9.2 \quad$ At least three INED directors?

9.3 If your answer in 6.2 is 'no', do you disclose the reason for not having at least three INED directors on the Board of Directors?

9.4 A majority of INED directors whom are members of other relevant governance structures in the firm?

9.5 Independent, non-executive directors who have a balance of relevant skills and experience in audit?

9.6 At least one INED director who has competence in accounting and/or auditing?

Comments:

'This question requires a response with regard to both, the transparency report (TR) and the integrated report (IR) disclosure'.

10 From the information disclosed on the Oversight Board, does the Oversight Board consist of:

10.1 A majority of INED directors?

10.2 At least three INED directors?

If your answer in 10.2 is 'no', do you disclose the reason for not having at least three INED directors on the Oversight Board? A majority of INED directors who are members of other relevant governance structures in the firm? Independent, non-executive directors who have a balance of relevant skills and experience in audit? At least one INED director who has competence in accounting and/or auditing?

With regard to the disclosure of information pertaining to the Board of Directors does the transparency report or the integrated report: State how the audit firm's Board of Directors operate their duties? State what type of decisions are made by the Board of Directors? State the names and job titles of all members of the Board of Directors? State how the members of the Board of Directors were elected or appointed? State the terms of the members of the Board of Directors? State the length of service of the members of the Board of Directors? State the meeting attendance in the year of the members of the Board of Directors? State any biographical details of the members of the Board of Directors? Include information on the appointment, retirement and resignation of INED directors? Include information on the remuneration of the INED directors? Include information on the duties of the INED directors? 
Comments:

Include how the supports the INED directors in discharging their duties?

Explain how the audit firm has positioned its INED directors (on the Board of Directors or the Oversight Board)?

State the criteria for assessing the impact of INED directors on the firm's independence as auditors and their independence

from the firm and its owners?

With regard to the disclosure of information pertaining to the Oversight Board does the transparency report or the integrated report:

State how the members of the Oversight Board were elected or appointed?

State the terms of the members of the Oversight Board?

State the length of service of the members of the Oversight Board?

State the meeting attendance in the year of the members of the Oversight Board?

State any biographical details of the members of the Oversight Board?

Include information on the remuneration of the INED directors?

12.11 Include information on the duties of the INED directors?

\footnotetext{
13

13.1

13.2

13.3

13.4

13.5

13.6

Comments:

With regard to the disclosure of information pertaining to risk management, does the transparency report or the integrated report: Disclose that a review was performed on the effectiveness of the system of internal control? Disclose which process was applied to perform a review on the effectiveness of the system of internal control? Disclose what weaknesses were identified in the review on the effectiveness of the system of internal control? Disclose what actions will be taken to deal with weaknesses identified in the review of the system of internal control? Disclose on the audit firm's website how the firm will support its commitment to the professionalism, openness and risk management?

Disclose on the auditing firms' website the whistle-blowing policies and procedures?
}

14 With reference to disclosure in the transparency report and the integrated report, does your auditing firm:

14.1 State how the firm applies policies and procedures for managing potential and actual conflicts of interest?

14.2 Include a commentary on the firm's performance, position and prospects?

14.3 Include fair and balanced information?

14.4 Explain everything in an understandable manner?

Comments:

To whom the code of conduct is applicable to? 
Does the auditing firm disclose information on any of the following committees:

$16.1 \quad$ Audit committee

16.2 Risk committee

16.3 Nomination committee

16.4 Remuneration committee

16.5 Ethics committee

Comments:

Comments:

Ethics committee

17 If the auditing firm has an audit committee, is it constituted according to the principles in King IV?

Comments:

'This question requires a response with regard to both, the transparency report (TR) and the integrated report (IR)'.

18 With reference to audited financial statements, does the auditing firm:

$18.1 \quad$ Publish audited financial statements?

18.2 Publish audited financial statements that are prepared in accordance with the recognised financial reporting framework?

18.3 Publish audited financial statements that are clear and concise?

18.4 Explain who is responsible for preparing the financial statements.

Comments:

INED, Independent non-executive directors. 